Neuro/mages

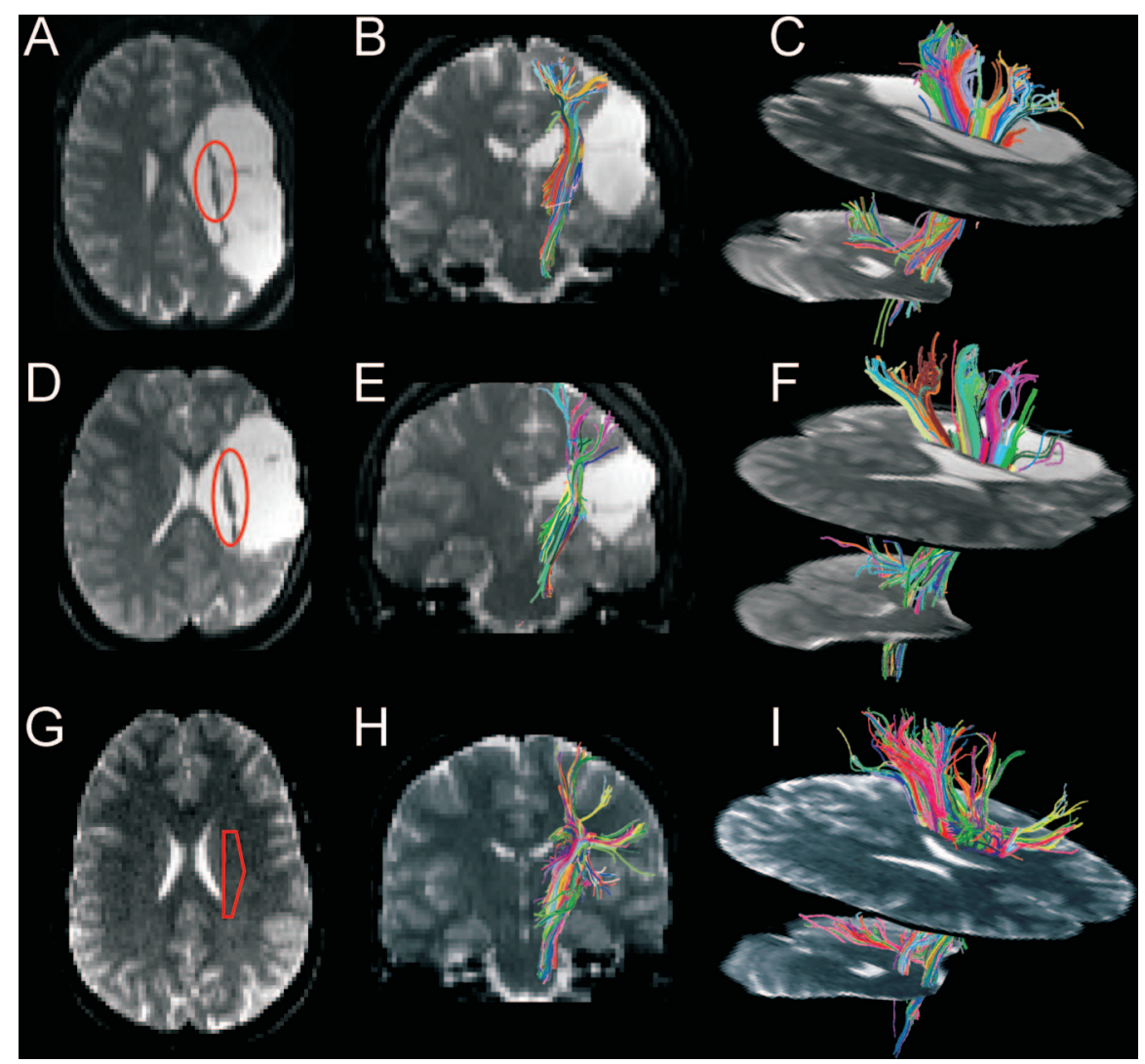

Figure. MR diffusion tensor tractography ${ }^{2}$ findings (Siemens AVANTO; 1.5 Tesla; $b=1000 \mathrm{~s} / \mathrm{mm}^{2}$; six diffusion directions; voxel size $2 \times 2 \times 2 \mathrm{~mm}^{3}$; fractional anisotropy $>0.2$; turning angle $\left.<65^{\circ}\right)$ of the two patients $(A-C$; $D-F)$ and a healthy 21-year-old woman $(G-I)$, displayed in random colors on unweighted $\left(b=0 \mathrm{~s} / \mathrm{mm}^{2}\right)$ diffusion images. $(A, D, G)$ Axial planes, inferior view (red $=$ region of interest for the tracking algorithm); (B, E, H) Coronal planes, anterior view; $(C, F, I)$ Tilted axial planes, anterior-lateral-superior view. In the control subject, the region of interest was drawn on a diffusion color map (not shown) to include all fibers with a cranio-caudal orientation of this axial plane.

\section{Extensive peri-lesional connectivity in congenital hemiparesis}

M. Staudt, MD; M. Erb, PhD; C. Braun, PhD;

C. Gerloff, MD, PhD; W. Grodd, MD, PhD; and

I. Krägeloh-Mann, $M D, P h D$, Tübingen, Germany

Two patients with congenital hemiparesis (\#5 and \#7 in reference $^{1}$ ) showed a striking discrepancy between large, pre- and perinatally acquired middle cerebral artery infarctions and relatively

Supported by the Deutsche Forschungsgemeinschaft (SFB 550 - C4, C5, C6 and STA 859-1).

Disclosure: The authors report no conflicts of interest.

Address correspondence and reprint requests to Dr. Martin Staudt, Department of Pediatric Neurology, University Children's Hospital, Hoppe-Seyler-Str. 1, D - 72076 Tübingen, Germany; e-mail: mnstaudt@med.uni-tuebingen.de preserved sensorimotor functions. Despite the large cystic lesions, the affected hemispheres possessed spino-thalamo-cortical somatosensory afferents as well as cortico-spinal motor efferents. This was shown by magnetoencephalography during repetitive tactile finger stimulation and focal transcranial magnetic stimulation. Accordingly, magnetic resonance (MR) diffusion tensor tractography ${ }^{2}$ (figure) visualized numerous trajectories passing through the narrow bridge of preserved white matter between the lateral ventricle and the infarcted area, providing extensive structural connectivity of fronto-parietal areas with the brainstem and the cerebellum. Although these findings are suggestive of a superior reorganizational capability of the developing human brain, further studies (including tractography data from patients with similar lesions acquired later in life) will be needed to clarify this point.

1. Staudt M, Gerloff C, Grodd W, Holthausen H, Niemann G, KrägelohMann I. Reorganization in congenital hemiparesis acquired at different gestational ages. Ann Neurol 2004;56:854-863.

2. Jiang H, Mori S. DTI Studio software, available at http://cmrm.med. jhmi.edu. 


\section{Neurology}

\section{Extensive peri-lesional connectivity in congenital hemiparesis \\ M. Staudt, M. Erb, C. Braun, et al. \\ Neurology 2006;66;771 \\ DOI 10.1212/01.wnl.0000201281.85209.8f}

\section{This information is current as of March 13, 2006}

Updated Information \&

Services

References

Subspecialty Collections

Permissions \& Licensing

Reprints including high resolution figures, can be found at:

http://n.neurology.org/content/66/5/771.full

This article cites 1 articles, 0 of which you can access for free at: http://n.neurology.org/content/66/5/771.full\#ref-list-1

This article, along with others on similar topics, appears in the following collection(s):

All Imaging

http://n.neurology.org/cgi/collection/all_imaging

Developmental disorders

http://n.neurology.org/cgi/collection/developmental_disorders

Plasticity

http://n.neurology.org/cgi/collection/plasticity

Information about reproducing this article in parts (figures,tables) or in its entirety can be found online at:

http://www.neurology.org/about/about_the_journal\#permissions

Information about ordering reprints can be found online:

http://n.neurology.org/subscribers/advertise

Neurology ${ }^{\circledR}$ is the official journal of the American Academy of Neurology. Published continuously since 1951, it is now a weekly with 48 issues per year. Copyright . All rights reserved. Print ISSN: 0028-3878. Online ISSN: 1526-632X.

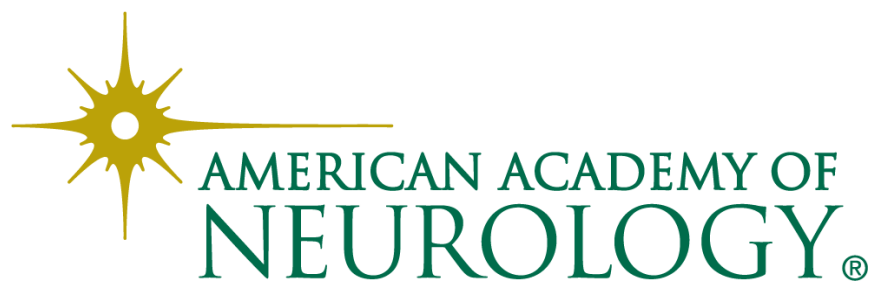

